\title{
In Vitro Simulation of Growth and Survival of Pseudomonas aeruginosa, P. fluorescence and P. putida under Cold Shock
}

\author{
Syeda Muntaka Maniha, Tasmin Tabassum, Tahsin Tabassum, Rashed Noor* \\ School of Life Sciences (SLS), Independent University, Bangladesh \\ E-mail: rashednoor@iub.edu.bd
}

\begin{abstract}
The experimental demonstration of bacterial growth is of large interest within the scientific community to chalk out the specific mechanisms underlying the survival strategies under adverse conditions in nature. An array of research has been conducted on heat shock as well as the related oxidative stresses using a range of bacterial species including Escherichia coli, Bacillus spp., Salmonella spp. and Pseudomonas spp. Present study further focused on the cold shock response within the species of the ubiquitous bacterium Pseudomonas. P. aeruginosa, P. fluorescence, and P. putida were subjected to cold shock by placing the corresponding cultures at low temperatures $\left(0^{\circ} \mathrm{C}\right.$ and $\left.8^{\circ} \mathrm{C}\right)$, and then their growth was assessed along with the necessary phenotypic observations. Interestingly, the pigmentation (green or bluish green pigments) was noticed almost in species at $37^{\circ} \mathrm{C}$ compared to those growing at lower temperatures. While at $37^{\circ} \mathrm{C}, P$. fluorescence showed the highest growth compared to the other two strains, at $8^{\circ} \mathrm{C}$ and even at $0^{\circ} \mathrm{C}, P$. putida showed the maximal growth followed by the growth of $P$. aeruginosa and then $P$. fluorescence.
\end{abstract}

Keywords: cold shock response, Pseudomonas aeruginosa, P. fluorescence, $P$. putida

\section{Introduction}

Lots of researches have so far shown that the bacterial growth and survival largely depends on (1) the limiting nutrients, (2) changes in temperatures, $\mathrm{pH}$, aeration condition, etc., (3) toxic chemicals like ethanol and hydrogen peroxide $\left(\mathrm{H}_{2} \mathrm{O}_{2}\right)$, accumulation of reactive oxygen species (ROS) especially in the early stationary phase of bacterial growth, (4) perturbations in other biotic and abiotic factors like the UV-irradiation, etc. ${ }^{[1-8]}$. Of them, temperature has been an important area of interest for many researchers to study the bacterial behavior under its variation; more specifically the stress response of bacterial cells especially under the high temperatures with the corresponding assessment of the culturable cells, the viable but non-culturable (VBNC) cells, expression of the stress responding relevant genes and proteins, and even by measuring the ROS levels at such stressed conditions ${ }^{[4,6,7,9-16]}$. The principal objective of these works probably underlies the investigation of the bacterial stress response since an extensive range of bacteria have been found to activate different transcriptional regulatory network (TRN) along with the up-regulation of an array of stress responsive genes under certain stress conditions ${ }^{[2,8,17]}$. As has been seen in our previous research, a large fraction of Escherichia coli cells lost culturability under heat stress and oxidative stress ${ }^{[4,6,7,15]}$. Our earlier studies also demonstrated the deterioration in the colony forming unit (CFU) of Pseudomonas spp. under oxidative stress. Compared to the study of heat shock, the effect of cold shock has not been investigated to a significant extent although the cold-shock responses involving the cold-shock proteins A (CspA), $\mathrm{CspB}, \mathrm{CspC}, \mathrm{CspE}, \mathrm{CapB}$ as well as the induction of genes encoding the universal stress factors RpoS and (p)ppGppare well known ${ }^{[18-22]}$.

Based on the background research on the bacterial cold shock response, present study further attempted to focus on the impact of such stress specifically on Pseudomonas aeruginosa, P. fluorescence, and P. putida. Examination for each of the strain's ability to survive at $0^{\circ} \mathrm{C}$ and $8^{\circ} \mathrm{C}$ was conducted and the corresponding culturability was assessed through their colony-forming ability.

Copyright (C2020, Rashed Noor, et al

DOI: https://doi.org/10.37256/amtt.112020285

This is an open-access article distributed under a CC BY license

(Creative Commons Attribution 4.0 International License)

https://creativecommons.org/licenses/by/4.0/ 


\section{Materials and methods}

Laboratory stock cultures of Pseudomonas aeruginosa, P. fluorescence, and P. putidawere were used. Growth was examined according to two aspects: (1) capacity of forming colony forming units (CFUs) on solid Luria-Bertani (LB) media under $37^{\circ} \mathrm{C}, 8^{\circ} \mathrm{C}$, and $0^{\circ} \mathrm{C}$; (2) observation of morphology and the phenotypes. Pre-cultures were prepared in $3 \mathrm{~mL}$ LB broth media incubated at $37^{\circ} \mathrm{C}$ for 4 hours under shaking conditions; the optical density (at $600 \mathrm{~nm}$ ) was adjusted at 0.1 ; and finally $30 \mu \mathrm{L}$ of the pre-cultures were introduced into $30 \mathrm{~mL} \mathrm{LB}$ media following incubation at $37^{\circ} \mathrm{C}, 8^{\circ} \mathrm{C}$, and $0^{\circ} \mathrm{C}^{[3,}$ ${ }^{15]}$. Culture growth was evaluated at different time intervals; $12,24,26,48,60$, and $72 \mathrm{~h}$ concerning the viability as colonyforming units (CFUs) on the agar plates using spot assay ${ }^{[3]}$. In addition, the morphological and phenotype characters of growing cultures were investigated.

\section{Results and discussion}

\subsection{Pigmentation during growth of Pseudomonas spp}

While $P$. aeruginosa and $P$. fluorescence are well known to produce phenazines pigment, the $P$. putida strains have been reported to produce anthocyanin pigment ${ }^{[23-25]}$. The pigmentation capacity of the strains was noticed in the following order: P. aeruginosa $>$ P. fluorescence $>$ P. putida. P. putida was not noticed to produce any greenish pigment; even at prolonged incubation; nevertheless, a brownish was seen after 72 hours (Table 1, Figure 1). As expected, cultures of the bacterial strains under investigation are colorless at $0^{\circ} \mathrm{C}$.

Table 1. Pigmentation pattern of Pseudomonas species at different temperatures

\begin{tabular}{|c|c|c|c|}
\hline Pseudomonas species & $0^{\circ} \mathrm{C}$ & $8^{\circ} \mathrm{C}$ & $37^{\circ} \mathrm{C}$ \\
\hline \multicolumn{4}{|l|}{ P. aeruginosa } \\
\hline 24 hours incubation & No pigmentation & No pigmentation & Dark greenish (pyocyanin) Pigment \\
\hline 72 hours incubation & & $\begin{array}{l}\text { Appearance of bluish green } \\
\text { pigment }\end{array}$ & $\begin{array}{c}\text { Dark greenish (pyocyanin) Pigment with more } \\
\text { fluorescence }\end{array}$ \\
\hline \multicolumn{4}{|l|}{ P. fluorescence } \\
\hline 24 hours incubation & No pigmentation & No pigmentation & Blue-greenish- and brownish pigment \\
\hline 72 hours incubation & & $\begin{array}{c}\text { Appearance of pale greenish } \\
\text { pigment }\end{array}$ & $\begin{array}{c}\text { Dark greenish (pyocyanin) Pigment with more } \\
\text { fluorescence }\end{array}$ \\
\hline \multicolumn{4}{|l|}{ P. putida } \\
\hline 24 hours incubation & No pigmentation & No pigmentation & Dark brown pigment \\
\hline 72 hours incubation & & $\begin{array}{c}\text { Appearance of pale brownish } \\
\text { pigment with a light bluish } \\
\text { ring }\end{array}$ & Dark brown pigment with a little fluorescence \\
\hline
\end{tabular}


P. aeruginosa
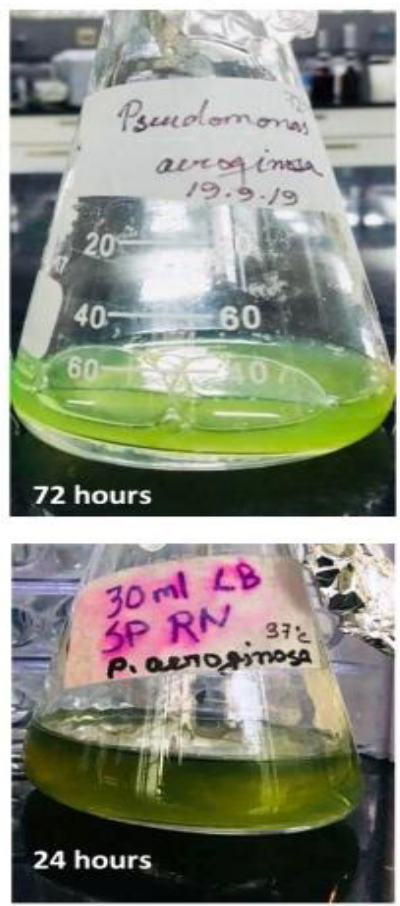

P. aeruginosa
P. fluorescence
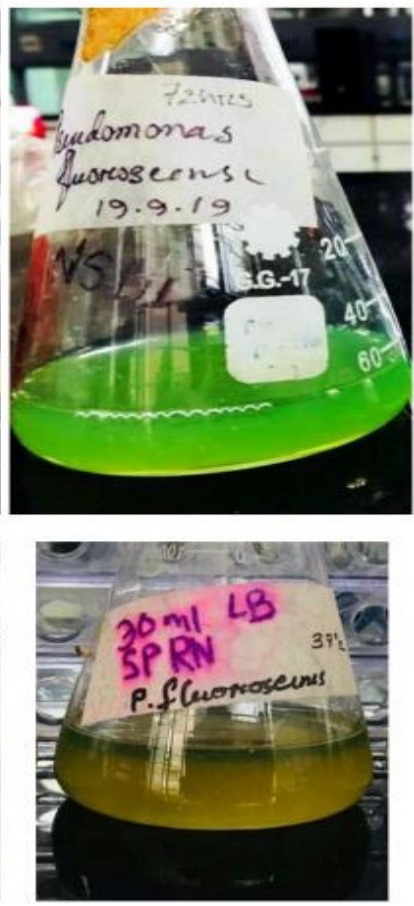

P. fluorescence
P. putida
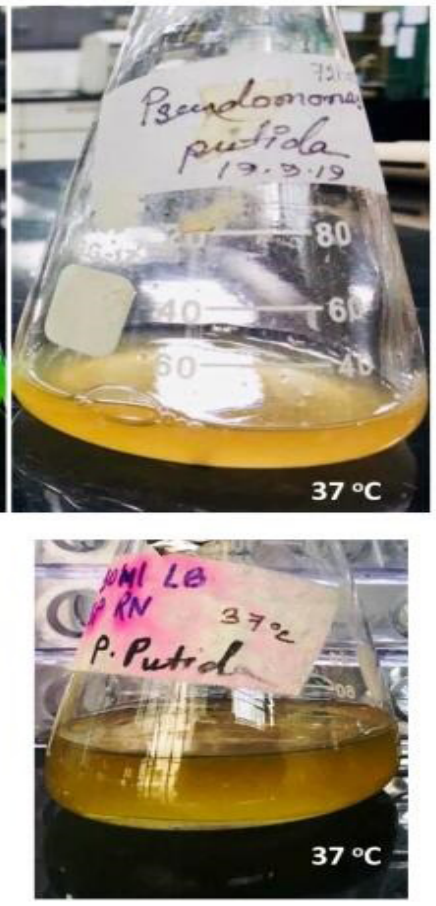

P. putida

Figure 1. Pigmentation pattern of Pseudomonas species at different temperatures. The representative image of pigment production at $37^{\circ} \mathrm{C}$ has been shown. For clarity of the observation, a tabular note has been inserted within the image. The pigmentation capacity of the Pseudomonas spp. strains was noticed to be in the order of $P$. aeruginosa $>$ P. fluorescence $>$ P. putida

The bluish green coloration of the P. aeruginosa and P. fluorescence is due to phenazines; it is a class that approximately contains fifty derivatives of heterocyclic secondary metabolites, which are usually produced during the stationary phase. Phenazines have long been reported as the reductants for molecular oxygen and ferric ions; participating in cell-to-cell communication, as well as they are known as antimicrobial agents ${ }^{[23,26]}$. Pyocyanin, the blue green phenazine pigment, is considered as a key virulence factor of Pseudomonas spp. Pyocyanin has been reportef to inactivate the host catalases and survive upon exposure to the reactive oxygen species (ROS) generated by the host tissues ${ }^{[23]}$. In addition, this pigment has also been reported to induce the destruction of neutrophils ${ }^{[27]}$. The results of the present study revealed the relatedness between the pigmentation rate of Pseudomonas spp. and the incubation temperature as well as the impact of cold shock on the pigmentation, which, so far our knowledge, has been noticed for the first time.

\subsection{Growth of Pseudomonas spp. at different temperatures}

The growth of Pseudomonas cells was assessed by the number of colony-forming units (CFUs). At $37^{\circ} \mathrm{C}$, the number of viable and culturable cells was increased as follows; $P$. fluorescence $>$ P. aeruginosa $>$ P. putida whereas the order is completely reversed at $8^{\circ} \mathrm{C}$ and $0^{\circ} \mathrm{C}$. Regarding results of spot assay, three Pseudomonas species under investigation at $48 \mathrm{~h}$ fail completely to grow on the agar plates at $0^{\circ} \mathrm{C}$. At $12 \mathrm{~h}$, bacteria grew well at $0^{\circ} \mathrm{C}$ as observed in figures 2 and 3 . 
$12 \mathrm{~h}$
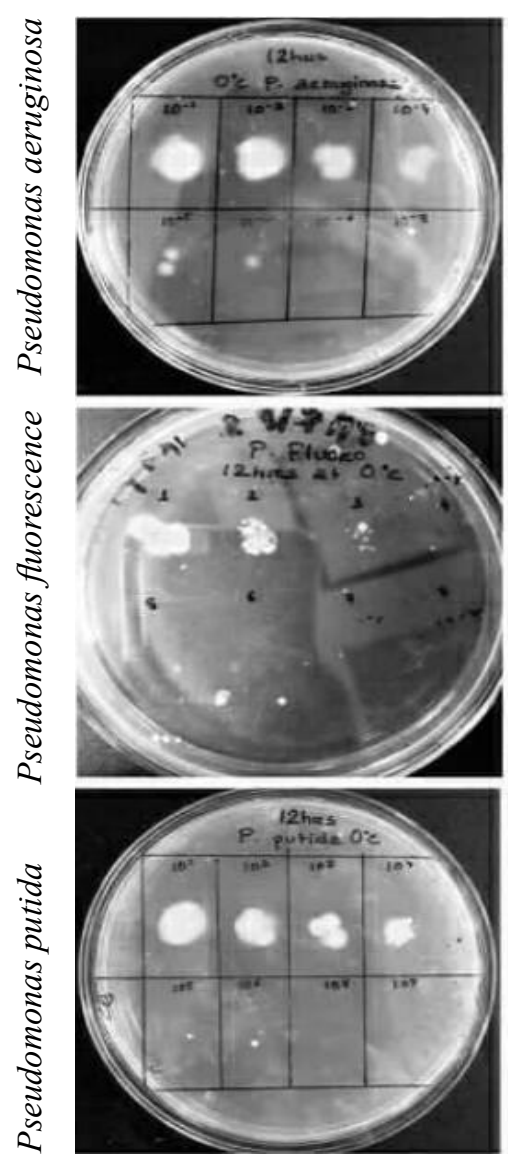

$8^{\circ} \mathrm{C}$
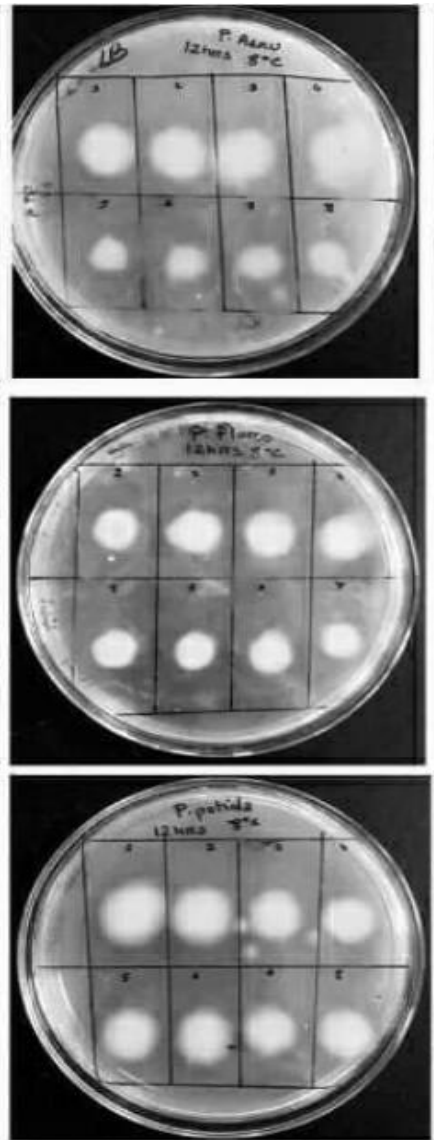

$37^{\circ} \mathrm{C}$
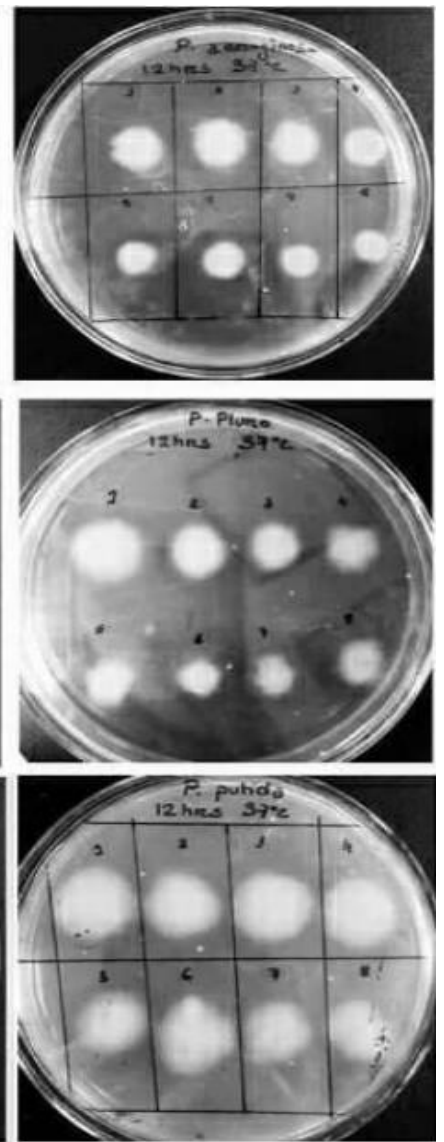

Figure 2. Stock cultures of Pseudomonas aeruginosa, $P$. fluorescence, and $P$. putida were subjecte $\mathrm{d}$ to be cultivated as discussed in the Materials and Methods. At $37^{\circ} \mathrm{C}$, the growth frequency was noticed in the order of $P$. fluorescence $>P$. aeruginosa $>P$. putida. Interestingly such order was completely opposite while growing at $8^{\circ} \mathrm{C}$ and $0^{\circ} \mathrm{C}$ 


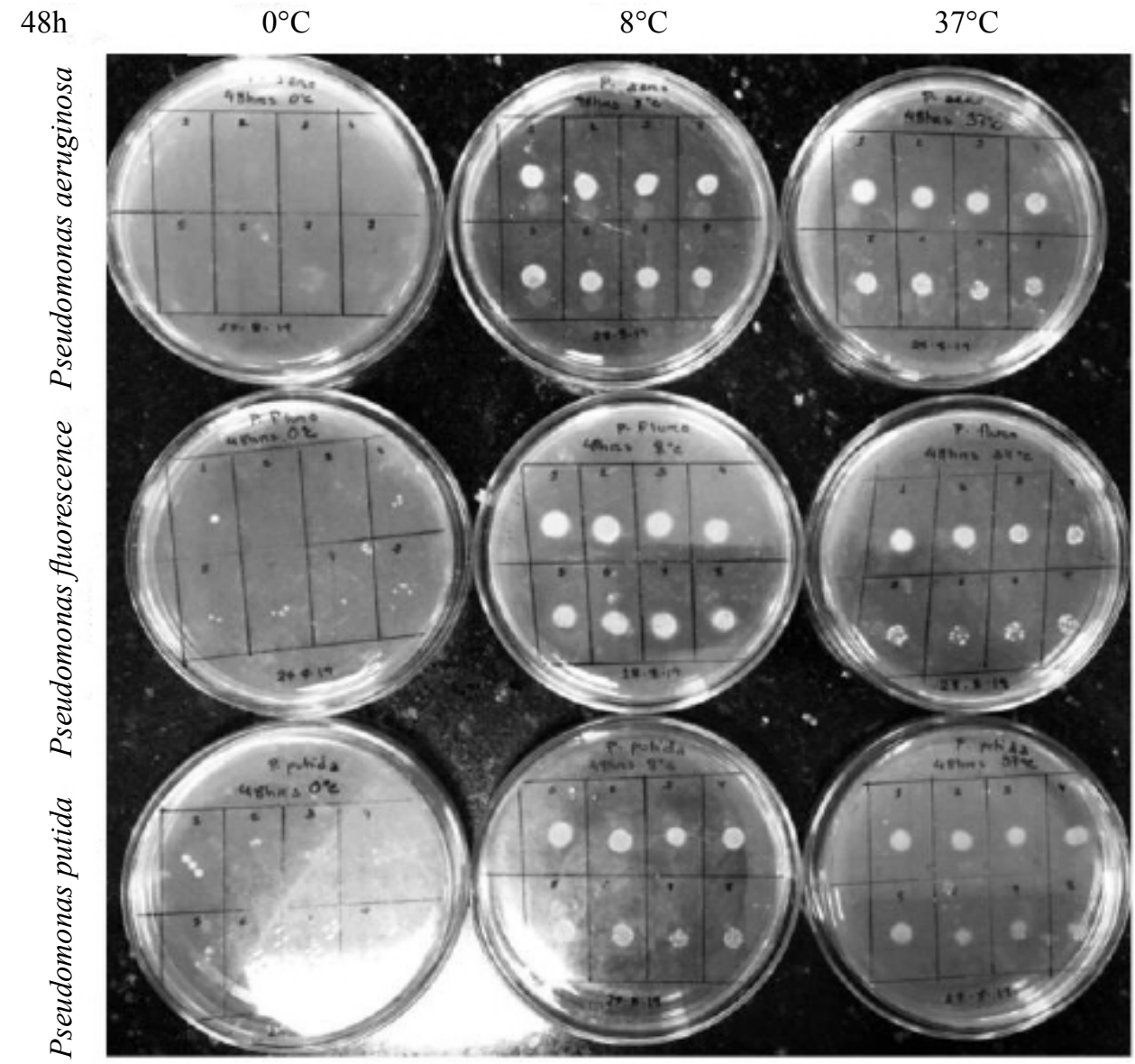

Figure 3. Spot tests were performed as stated in Figure 2. The only difference is that in this case the aliquots from the stationary phase (48h) were used. All species failed to grow on the agar plates at $0^{\circ} \mathrm{C}$ after $48 \mathrm{~h}$

With a similar mode of our findings, an array of Pseudomonas species have been found to grow glowing between $5^{\circ} \mathrm{C}$ and $10^{\circ} \mathrm{C}$, and even at $0^{\circ} \mathrm{C}$ as reported earlier ${ }^{[28]}$. Due to the ubiquitous nature of Pseudomonas spp., knowledge on the cold shock resistance traits from the current research would be fruitful because of their particular clinical impacts (multidrug-resistant, MDR- and the carbapenem-resistant P. putida and P. aeruginosa) and their capacity to contaminate different food items like milk, meat, fish, vegetables, etc. ${ }^{[29,30]}$. Additionally, the pigmentation of Pseudomonas species as evaluated in the current study may be further investigated for their possible role in disease progression.

Finally, it would be more interesting to ponder the molecular strategies for the growth and survival of Pseudomonas species against cold shock; particularly by studying the $\operatorname{cap} \mathrm{B}, \operatorname{csp} \mathrm{A}$ genes (encoding the major cold shock proteins) ${ }^{[19,}$ ${ }^{30]}$. However, our study clearly demonstrated the cold shock tolerance traits of different Pseudomonas species which may further come in help to study not only the protective management system against environmental stresses but also would benefit the understanding of the propagation of food spoilage microorganisms and the clinically oriented pathogens.

\section{Acknowledgement}

Authors are thankful to the Microbiology Laboratory of the School of Life Sciences (SLS), Independent University, Bangladesh (IUB) for the logistic support. However, no research grant was received to conduct this research.

\section{Funding}

There was no fund for conducting this research.

\section{Competing Interest}

Authors declared that they have no conflict of interest. 


\section{References}

[1] Choudhury NN, Nur IT, Munna MS, Noor R. Comparative Study of oxidative stress response in Pseudomonas aeruginosa (Subp01) and Pseudomonas fluorescence (Subp02) upon external stimulation by hydrogen peroxide. EC Microbiology. 2019; 15: 653-660.

[2] Noor R. Mechanism to control the cell lysis and the cell survival strategy in stationary phase under heat stress. SpringerPlus. 2015; 4: 599.

[3] Munna MS, Tahera J, Afrad MH, Nur IT, Noor R. Survival of Bacillus spp. SUBB01 at high temperatures and a preliminary assessment of its ability to protect heat-stressed Escherichia coli cells. BMC Res Notes. 2015; 8: 637.

[4] Murata M, Noor R, Nagamitsu H, Tanaka S, Yamada M. Novel pathway directed by $\sigma^{\mathrm{E}}$ to cause cell lysis in Escherichia coli. Genes Cells. 2012; 17: 234-247.

[5] Bren A, Hart Y, Dekel E, Koster D, Alon U. The last generation of bacterial growth in limiting nutrient. BMC Systems Biology. 2013; 7: 27.

[6] Noor R, Murata M, Nagamitsu H, Klein G, Raina S, Yamada M. Dissection of $\mathrm{s}^{\mathrm{E}}$-dependent cell lysis in Escherichia coli: Roles of RpoE regulators RseA, RseB and periplasmic folding catalyst PpiD. Genes Cells. 2009; 14: 885-899.

[7] Noor R, Murata M, Yamada M. Oxidative stress as a trigger for growth phase-specific $\mathrm{s}^{\mathrm{E}}$-dependent cell lysis in Escherichia coli.J Mol Microbiol Biotechnol. 2009; 17: 177-187.

[8] Boor KJ. Bacterial stress responses: What doesn't kill them can make them stronger. PLoS Biology. 2006; 4: e23.

[9] Hou L, Wang L, Wu X, Gao W, Zhang J, Huang C. Expression patterns of two pal genes of Pleurotusostreatus across developmental stages and under heat stress. BMC Microbiol. 2019; 19: 231.

[10] Noor R, Tabassum T, Tabassum T, Tabassum N, Maniha SM. Growth and survival of Pseudomonas species under cold shock. Acta Scientific Microbiology. 2019; 1: 10-13.

[11] Noor R, Munna MS, TabassumN, Maniha SM, Tabassum T, Tabassum T. Stress responses within Bacillus species under heat shock. Acta Scientific Microbiology. 2019; 2, 148-153.

[12] Zhao X, Zhong J, Wei C, Lin C-W, Ding T. Current perspectives on viable but non-culturable state in foodborne pathogens. Frontiers in Microbiology. 2017; 8: 580.

[13] Chen L, Zhu X, Zhang M, Wang Y, Lv T, Zhang S, Yu X. Profiling total viable bacteria in a hemodialysis water treatment system. J Microbiol Biotechnol. 2017; 27: 995-1004.

[14] Li L, Mendis N, Trigui H, Oliver, JD, Faucher SP. The importance of the viable but non-culturable state in human bacterial pathogens. Frontiers in Microbiology. 2014; 5: 258.

[15] Nur IT, Munna MS, Noor R. Study of exogenous oxidative stress response in Escherichia coli, Pseudomonas spp., Bacillus spp. and Salmonella spp. Turkish Journal of Biology. 2014; 38: 502-509.

[16] Oliver JD. Recent findings on the viable but nonculturable state in pathogenic bacteria. FEMS Microbiology Reviews. 2010; 34: 415-425.

[17] Ledezma-Tejeida D, Altamirano-Pacheco L, Fajardo V, Collado-Vides J. Limits to a classic paradigm: Most transcription factors in E. coli regulate genes involved in multiple biological processes. Nucleic Acids Res. 2019; 47: 6656-6667.

[18] Michaux C, Holmqvist E, Vasicek E, Sharan M, Barquist L, Westermann AJ, Gunn JS, Vogel J. RNA target profiles direct the discovery of virulence functions for the cold-shock proteins CspC and CspE. Proc Natl Acad Sci. 2017; 114: 6824-6829.

[19] Bisht SC, Joshi GK, Mishra PK. CspA encodes a major cold shock protein in Himalayan psychrotolerant Pseudomonas strains. Interdiscip Sci. 2014; 6: 140-148.

[20] Kumar A, Khan M. Prediction of ligand binding site by in silico approach in cold resistant protein isolated from cold resistant mutant of Pseudomonas fluorescence. J Mol Graph Model. 2012; 38: 101-111.

[21] Shenhar Y, Biran D, Ron EZ. Resistance to environmental stress requires the RNA chaperones CspC and CspE. Environ Microbiol Rep. 2012; 4, 532-529.

[22] Panicker G, Mojib N, Nakatsuji T, Aislabie J, Bej AK. Occurrence and distribution of capB in Antarctic microorganisms and study of its structure and regulation in the Antarctic biodegradativePseudomonas sp. 30/3. Extremophiles. 2009; 14: 171-183.

[23] VanLaar TA, Esani S, Birges TJ, Hazen B, Thomas JM, Rawat M. Pseudomonas aeruginosagshA mutant is defective in biofilm formation, swarming, and pyocyanin production. mSphere. 2018; 3: e00155-18.

[24] El-Foulya MZ, Sharaf AM, Shahin AAM, El-Bialy HA, Omar AMA. Biosynthesis of pyocyanin pigment by Pseudomonas aeruginosa. Journal of Radiation Research and Applied Sciences. 2015; 8: 36-48.

[25] Zulueta-Rodriguez R, Cordoba-Matson MV, Hernandez-Montiel LG, Murillo-Amador B, Rueda-Puente E, Lara L. Effect of Pseudomonas putidaon growth and anthocyanin pigment in two poinsettia (Euphorbia pulcherrima) cultivars. Scientific World Journal. 2014; 810192. 
[26] Mavrodi DV, Parejko JA, Mavrodi OV, Kwak YS, Weller DM, Blankenfeldt W, Thomashow LS. Recent insights into the diversity, frequency and ecological roles of phenazines in fluorescent Pseudomonas spp. Environ Microbiol. 2013; 15: 675-686.

[27] Managò A, Becker KA, Carpinteiro A, Wilker B, Soddemann M, Seitz AP, Edwards MJ, Grassmé H, Szabò I, Gulbins E. Pseudomonas aeruginosapyocyanin induces neutrophil death via mitochondrial reactive oxygen species and mitochondrial acid sphingomyelinase. Antioxid Redox Signal. 2015; 22, 1097-1110.

[28] Moreno R, Rojo F. Features of pseudomonads growing at low temperatures: another facet of their versatility. Environ Microbiol Rep. 2014; 6: 417-426.

[29] Franzetti L, Scarpellin M. Characterization of Pseudomonas spp. isolated from foods. Annals of Microbiology. 2007; 57: 39-47.

[30] Kim SE, Park SH, Park HB, Park KH, Kim SH, Jung SI, Shin JH, Jang HC, Kang SJ. Nosocomial Pseudomonas putida bacteremia: High rates of carbapenem resistance and mortality. Chonnam Med J. 2012; 48: 91-95. 